TEME, г. XLI, бр. 3, јул - септембар 2017, стр. 711-730

Претходно саопштење

DOI: $10.22190 /$ TEME1703711B

Примљено: 5. 7. 2016

UDK 339.56:338.43](497.11)

Ревидирана верзија: 4. 2. 2017.

Одобрено за штампу: 15. 6. 2017.

\title{
СПОЉНОТРГОВИНСКА РАЗМЕНА СРБИЈЕ И ЗНАЧАЈ АГРАРНОГ СЕКТОРА
}

\author{
Драгица Божић*, Марија Николић \\ Универзитет у Београду, Пољопривредни факултет, Београд, Србија \\ bozdrag@agrif.bg.ac.rs
}

\begin{abstract}
Апстракт
Спољнотрговинску размену укупне економије Србије карактерише велики дефицит и неповољна структура. Значај аграрног сектора у укупној размени огледа се у непрестаном позитивном спољнотрговинском салду и повећавању учешћа, првенствено у извозу. Циљ рада је анализа основних обележја спољнотрговинске размене Србије, као и указивање на значај аграрног сектора у периоду 2005-2014. године. У првом делу рада анализиран је тренд извоза, увоза, као и степен отворености српске економије. У наставку је разматрана структура извоза и увоза, обрачунати су индекси концентрације, односно Herfindahl-Hirschmann индекс, као и индекси диверзификације који указују на разлику између структуре извоза и увоза Србије и светског просека. Поред ових показатеља, обрачунат је и индикатор откривене компаративне предности. Анализа спољнотрговинске размене укупне економије Србије указује на значајну заступљеност пољопривредно-прехрамбених производа у њеној структури, посебно извозу, и потврђује да аграрни сектор представља један од ретких сектора који константно остварује суфицит. Компаративне предности у размени укупне економије Србије са светом остварене су, првенствено, код примарних производа и производа ниже фазе прераде, од којих је значајан део из аграрног сектора.
\end{abstract}

Кључне речи: спољнотрговинска размена, показатељи успешности спољне трговине, индекс концентрације и диверзификације, аграрни сектор, откривена компаративна предност.

\section{SERBIAN FOREIGN TRADE AND IMPORTANCE OF AGRARIAN SECTOR}

\begin{abstract}
The foreign trade of the Serbian economy is characterized by a large deficit and unfavourable structure. The importance of the agrarian sector in total trade is reflected in the constant positive trade balance and increasing participation, particularly in export. The aim of the paper is to analyze the basic characteristics of foreign trade of Serbia, as well as to point out the importance of the agrarian sector in the period 20052014. In the first part of the paper are analyzed trends of export, import, and the level
\end{abstract}


of openness of Serbian economy. In the following part the structure of export and import is discussed, and the concentration index presented, or the Herfindahl-Hirschmann index, as well as the diversification index which indicates the difference between the structure of Serbian export and import and the international average. In addition to these indicators, the revealed comparative advantage index was calculated. The analysis of foreign trade of Serbian overall economy indicates a significant presence of agricultural and food products in its structure, particularly in export, and confirms that the agrarian sector is one of few sectors with a constant surplus. Determined indicators show that the comparative advantage in the overall economy trade of Serbia with the world is achieved in primary products and products of lower processing phase, of which a significant part is from the agrarian sector. Therefore, in the final part of the paper the participation of the agrarian sector in the total foreign trade of Serbia is shown.

Key words: foreign trade, foreign trade performance indicators, the index of concentration and diversification, agrarian sector, revealed comparative advantage.

\section{1. УВОД}

Светску привреду карактерише растућа међузависност националних привреда и јачање интегративних процеса који умногоме опредељују карактеристике укупне међународне трговине. Колико ће једна земља бити укључена и успешна у међународној размени зависи од њене привредне структуре и степена привредног развоја, техничкотехнолошког нивоа развијености и достигнутог нивоа продуктивности и конкурентности. Виши степен привредне развијености и повољнија привредна структура, по правилу, смањују увозну зависност земље, а повећавају њену зависност од извоза.

Спољнотрговинску размену Србије карактерише константан дефицит, који је у последњој деценији прошлог века увећан као резултат бројних унутрашњих и спољних ограничења, међу којима су: распад државе, економске санкције УН, ратови вођени на територији бивших република, бомбардовање НАТО и др. Дефицит спољнотрговинске размене Србије додатно је повећан у условима светске економске кризе, првенствено услед смањења страних директних инвестиција и извоза. Превазилажење неповољног биланса спољнотрговинске размене укупне економије захтева повећање вредности и конкурентности извоза, која је ниска како у односу на земље ЕУ тако и чланице CEFTA, односно земље у окружењу. Да би се то остварило, неопходна су значајна инвестициона улагања у урушену привреду Србије и нове технологије, што није могуће остварити без значајнијег прилива иностраних средстава.

Циљ рада је да се анализирају основна обележја укупне спољнотрговинске размене Србије и укаже на допринос аграрног сектора у периоду 2005-2014. године, при чему је обухваћена спољнотрговинска размена роба. У првом делу рада анализиран је степен отворености, односно зависности привредног развоја земље 
од спољне трговине, склоност ка извозу и увозу, тренд извоза, увоза и дефицита укупне размене Србије. Као метод за утврђивање степена концентрације на нивоу укупног извоза и увоза коришћен је индекс концентрације. Индекс диверзификације послужио је да се утврди колико се структура извоза и увоза Србије разликује од структуре просечног извоза и увоза на светском нивоу. У наставку је разматрана структура спољнотрговинске размене, као и степен покривености увоза извозом (према секторима, односно групама производа). У циљу свеобухватније анализе компаративних предности, односно конкурентности појединих сектора, обрачунат је индикатор откривене компаративне предности (RCA - Revealed Comparative Advantage).

Један од значајно заступљених сектора у структури спољнотрговинске размене Србије, посебно у извозу, представља аграрни сектор. У наставку рада приказан је значај аграрног сектора у укупној спољнотрговинској размени Србије. Индикатор откривене компаративне предности послужио је и за сагледавање компаративне предности појединих група производа унутар аграрног сектора Србије у размени са светом.

\section{2. ТЕОРИЈСКИ ОКВИР ИСТРАЖИВАЬА}

Међународна трговина представља најзначајнију везу између националних привреда у свету. Као показатељ степена зависности привредног развоја једне земље од спољне трговине користи се коефицијент отворености привреде или зависности земље од спољне трговине. Мери се преко учешћа извоза, увоза и укупне спољнотрговинске размене у бруто домаћем производу (БДП). Испитивање корелационе повезаности резултата у развоју спољне трговине и других макроекономских показатеља у настојању да се докаже утицај спољне трговине на стабилност привредних токова и превазилажење различитих врста криза били су предмет бројних истраживања (Јаћимовић и сар., 2013; Бољановић, 2013).

Поред значајне позитивне трговинске динамике у региону пре кризе, структура трговине земаља Западног Балкана остала је проблематична. Обим увоза удвостручио се код већине земаља, указујући на то да су земље региона веома увозно оријентисане (Јаћимовић и сар., 2013). Непрестано присутан проблем у трговинском билансу свих земаља Југоисточне Европе изазван је ниским нивоом конкурентности и озбиљним развојним дисбалансима. Стране директне инвестиције у Србији су у претходном периоду биле претежно усмерене у тржишно оријентисане активности које припадају терцијарном сектору, што није допринело решавању проблема са сталним спољнотрговинским дефицитом (Бољановић, 2013). 
Концепт отворености земаља сагледаван је најчешће из угла утицаја на економски раст и развој, док је однос отворености, као основне мере укључивања у светске привредне токове, и конкурентности, уопштено гледано, мало истраживан. Поједини аутори сугеришу да у анализи отворености треба разликовати извозне и увозне токове, будући да је веза између отворености на страни извоза и конкурентности далеко јача у односу на везу између отворености на страни увоза и конкурентности (Тешић, 2013).

Према теорији апсолутних предности коју је развио Адам Смит, државе треба да се специјализују у извозу оних производа у чијој производњи имају апсолутну предност у односу на друге државе. Специјализација у производњи одређених производа зависи од расположивости природних, људских и техничких ресурса које земља поседује. Више од половине западноевропских земаља специјализовало се за производњу у којој се користи висока и средње висока технологија, док је то случај само са једном трећином укупног броја земаља централне и источне Европе (Olteanu, 2009).

Структура извоза Србије, у којој доминирају радно и ресурсно интезивни производи, може се означити као неповољна и одговара структури извоза ниско развијених земаља (Jeferson Institut, 2003). Раст српског извоза у протеклим годинама није праћен знатним побољшањем његове квалитативне структуре, већ форсирањем производа у чијој се производњи користи ниска технологија, што подсећа на почетак 1980-их, када је тешка платно-билансна ситуација практично промовисала политику „извоза по сваку цену” (Бољановић, 2013).

Бројна истраживања указују на то да су могућности српске привреде за повећање извоза недовољно искоришћене, а као основни разлог заостајања наводи се ниска конкурентност, не само у односу на земље чланице ЕУ већ и у односу на земље у окружењу. Све теже испуњавање високих захтева тржишта ЕУ у погледу квалитета, али и адекватних количина, односно стабилности у снабдевању, може условити у наставку процеса интеграција и либерализације тржишта даљи раст трошкова прилагођавања тим захтевима (Божић, Николић, 2013-б). Повећање вредности извоза роба захтева значајна инвестициона улагања у девастирану српску привреду (Jefferson Institute, 2003; Јаћимовић и сар., 2013; Бољановић, 2013). У економској теорији не постоји јединствена дефиниција конкурентности. Појам конкурентности може се посматрати са макро и микро аспекта. Макро конкурентност односи се на конкурентност националних економија у целини, док микро конкурентност у средиште анализе ставља предузеће, односно групе предузећа, при чему се истиче да је национална конкурентска предност резултат конкурентности свих предузећа.

Мерење конкурентности и компаративних предности заснованих на различитим теоријама ствара бројне потешкоће. Отуда је Ба- 
ласа (Balassa, 1965), у настојању да се превазиђу проблеми обрачуна стварних компаративних предности појединих сектора и њиховог поређења између земаља, пошао од података о извозу и увозу и на основу њих дефинисао концепт откривене компаративне предности (Revealed Comparative Advantage Index - RCA) земље. ${ }^{1}$ Баласа индекс, односно дефиниција RCA, често су мењани и данас постоје бројни модификовани показатељи (Fertö and Hubbard, 2002; Bojnec and Fertö, 2007; Божић и Николић, 2013-а). Услед коришћења великог броја различитих индикатора за обрачун RCA наведених у литератури, могу се јавити неконзистентни резултати о нивоу компаративне предности. Стога ствараоци политике морају опрезно тумачити RCA индексе и доносити закључке о (не)постајању компаративних предности (Божић и Николић, 2013-а).

\section{3. МЕТОД РАДА И ИЗВОРИ ПОДАТАКА}

Као показатељ анализе учешћа једне земље у размени са другим земљама и за мерење степена зависности њеног привредног развоја од спољне трговине користи се коефииијент отворености привреде или зависности земље од спољне трговине. Мери се преко учешћа извоза, увоза или укупне трговинске размене у бруто домаћем производу (БДП).

Склоност извозу, односно показатељ зависности земље од извоза, представља учешће извоза у БДП земље у одређеној години. Склоност увозу, односно показатељ зависности земље од увоза, представља учешће увоза у БДП земље у одређеној години. Укупна зависност земље од извоза и увоза (спољне трговине), односно коефииијент отворености економије ка трговини, утврђује се као учешће укупне размене у БДП.

За утврђивање положаја једне државе и њене успешности на светском тржишту могу се користити различити показатељи. У литератури се најчешће наводе следећи индикатори:

- Индекс диверзификаиије извоза и увоза показује колико се структура извоза (увоза) земље разликује од структуре просечног извоза (увоза) на светском нивоу. Индекс представља модификован Finger-Kreinin индекс ${ }^{2}$ за мерење сличности трговине, а израчунава се сабирањем апсолутних одступања учешћа производа у структури извоза (увоза) зем-

\footnotetext{
${ }^{1}$ Пре него што је Balassa представио свој индекс откривене компаративне предности (RCA) 1965. године, Liesner je (1958) већ дао свој допринос емпиријском истраживању RCA.

2 За више информација видети Finger, J. М. and М. E. Kreinin (1979), “A measure of 'export similarity' and its possible uses" in the Economic Journal, 89: 905-912.
} 
ље у односу на њихово учешће у укупном светском извозу (увозу), коришћењем следеће формуле:

где је:

$$
\mathrm{S}_{\mathrm{j}}=\frac{\sum_{i}\left|h_{i j}-h_{i}\right|}{2},
$$

$S_{j}-$ индекс диверзификације извоза (увоза) одређене земље или групе земаља $j$;

$h_{i j}$ - удео производа $i$ у укупном извозу (увозу) земље или групе земаља $j$;

$h_{i}-$ удео производа $i$ у укупном светском извозу (увозу).

Индекс диверзификације може имати вредност између 0 и 1. Вредности индекса ближе 1 означавају већу разлику у односу на структуру просечног извоза/увоза на светском нивоу. Мале економије са скромним ресурсима и домаћим тржиштем нису у могућности да успешно развијају све привредне гране и остварују значајнију диверзификацију производње и извоза, те стога имају веће вредности индекса диверзификације и значајније одступање од структуре извоза на светском нивоу.

- Индекс конщентраиије или Herfindahl-Hirschmann индекс користи се као један од показатеља степена концентрације на нивоу целокупног извоза (увоза). Обрачунава се на основу свих производа на троцифреном нивоу СМТК класификације у извозу (увозу) једне земље на основу следеће формуле:

$$
\mathrm{H}_{\mathrm{j}}=\frac{\sqrt{\sum_{i=1}^{n}\left(\frac{x_{i j}}{X j}\right)^{2}-\sqrt{1 / n}}}{1-\sqrt{1 / n}},
$$

где је:

$H_{j}$ - индекс концентрације извоза (увоза) одређене земље или групе земаља $j$;

$x_{i j}$ - вредност извоза (увоза) одређеног производа $i$ за земљу или групу земаља $j$;

$X j$ - вредност укупног извоза (увоза) земље $j X_{j}=\sum_{i=1}^{n} x_{i j}$;

$n$ - број производа (на троцифреном нивоу СМТК класификације).

Индекс концентрације може имати вредности између 0 и 1 , при чему вредност индекса ближа нули указује на то да је специјализација, односно концентрација нижа, с обзиром на то да постоји велика диверзификација извоза. Уколико је вредност индекса концентрације ближа 1 , то је специјализација виша, односно извоз/увоз одређене земље је високо концентрован на неколико производа (UNCTAD). Овај индекс сматра се посебно важним за земље у развоју, јер су многе од њих често веома зависне од релативно малог броја примарних производа у извозу (World Bank, WITS). 
- Индекс откривене компаративне предности RCA или Баласа индекс је општеприхваћен метод за анализу трговинских података којим се мери компаративна предност једне земље. Баласа индекс омогућава да се утврди да ли земља (сектор) има „откривене” компаративне предности, а не и који су основни извори тих предности (Божић и Николић, 2013-а). У овом раду Баласа индекс је обрачунат коришћењем следеће формуле:

где је:

$$
\operatorname{RCA}_{i j}=\frac{\left(X_{i j}-M_{i j}\right)}{X_{i j}+M_{i j}},
$$

$\mathrm{RCA}_{\mathrm{ij}}$ - индекс откривене компаративне предности у трговини производом $i$ земље $j$;

$\mathrm{X}_{\mathrm{ij}}-\quad$ вредност извоза производа $i$ земље $j$;

$\mathrm{M}_{\mathrm{ij}}-\quad$ вредност увоза производа $i$ земље $j$.

На нивоу укупне трговине, показатељ RCA представља однос спољнотрговинског салда одређене земље и укупног обима размене земље са светом. Вредност индекса креће се од -1 до 1 . Позитивна вредност RCA за одређену групу производа значи да земља има компаративне предности (суфицит) у трговини тим производом.

За анализе у овом истраживању као извори података послужили су база података и публикације Републичког завода за статистику Србије. Коришћена је Стандардна међународна трговинска класификација - CMTK - рев. 4 (SITC). Према наведеној класификацији, аграрни сектор (пољопривредно-прехрамбени производи) обухвата секторе: 0 - Храна и живе животиње (робни одсеци: $1-9$ ); 1 - Пића и дуван (робни одсеци: 11, 12); 2 - Сирове материје, осим горива: (робни одсеци $21,22,29)$ и 4 - Животињска и биљна уља и масти (робни одсеци: 41-43).

\section{4. ОБЕЛЕЖЈА СПОЉНОТРГОВИНСКЕ РАЗМЕНЕ УКУПНЕ ЕКОНОМИЈЕ СРБИЈЕ}

Континуирани раст спољнотрговинске активности српске привреде присутан је до 2008. године, при чему је бржи раст вредности увоза од извоза, као резултат либерализације, утицао на продубљивање дефицита, који је у овој години достигао највиши ниво у анализираном периоду од преко 13 милијарди УСД (Графикон 1). Са глобалном економском кризом и бржим падом вредности увоза од вредности извоза, у 2009. години смањен је укупни спољнотрговински дефицит Србије. У наредним годинама уследио је опоравак и пораст вредности спољнотрговинске размене Србије. 
Приказани подаци о вредности укупног извоза и увоза, као и стално присутан дефицит робне размене, указују на низак ниво конкурентности српске привреде, као и на то да релативно расположиви природни ресурси не могу бити довољан услов развоја и динамичнијег раста извоза. Према подацима Светског економског форума, српска економија је међу најмање конкурентним привредама, не само у односу на земље ЕУ већ и у односу на земље у окружењу. ${ }^{3}$

Табела 1. Основни показатељи успешности спољнотрговинске размене роба укупне економије Србије у периоду 2005-2014. године

\begin{tabular}{lrrrr}
\hline Показатељи & $\varnothing(2005$ & $\varnothing(2008$ & $\varnothing(2011$ & 2014 \\
& $-2007)$ & $-2010)$ & $-2013)$ & \\
\hline БДП (мил. УСД) & $32.394,3$ & $43.759,6$ & $44.217,2$ & $44.143,1$ \\
Извоз - укупно (мил. УСД) & $6.577,1$ & $9.702,7$ & $12.539,1$ & $14.845,2$ \\
Удео извоза у БДП - склоност извозу (\%) & 20,0 & 22,2 & 28,4 & 33,6 \\
Увоз - укупно (мил. УСД) & $14.263,1$ & $18.866,7$ & $19.779,7$ & $20.609,1$ \\
Удео увоза у БДП - склоност увозу (\%) & 43,5 & 42,8 & 44,8 & 46,7 \\
Коефицијент отворености - & $\mathbf{6 3 , 4}$ & $\mathbf{6 5 , 0}$ & $\mathbf{7 3 , 2}$ & $\mathbf{8 0 , 3}$ \\
удео извоза и увоза у БДП (\%) & & & & \\
Салдо - укупно (мил. УСД) & $-7.686,0$ & $-9.164,0$ & $-7.240,6$ & $-5.764,0$ \\
Покривеност увоза извозом (\%) & 45,9 & 52,5 & 63,2 & 72,0 \\
Откривена компаративна предност (RCA) & $-0,37$ & $-0,31$ & $-0,23$ & $-0,16$ \\
\hline \multicolumn{1}{c}{ Извор: Обрачун аутора на основу база података Р3С и UNCTAD }
\end{tabular}

Спољнотрговинска политика Србије у периоду након 2000. године значајно је либерализована, што се односи и на читав регион. Кроз аутономне трговинске олакшице ЕУ, Споразум о стабилизацији и придруживању са ЕУ, СЕFТА 2006. и бројне друге споразуме о слободној трговини, долази до постепеног интегрисања земље у међународне трговинске токове. Процес приступања Републике Србије Светској трговинској организацији (WTO) приводи се крају, а спољнотрговинска политика се усаглашава са захтевима ове организације, која данас укључује 164 земље и преко 97\% укупне светске трговине. У

\footnotetext{
${ }^{3}$ Анализа конкурентности земаља у глобалним оквирима најчешће се сагледава на основу података Светског економског форума (CЕФ) и њиховог Индекса глобалне конкурентности. Погоршање ионако ниске конкурентске позиције српске економије након избијања финансијске кризе у 2009. години знатно је веће него код осталих земаља, док је пад вредности индекса у 2013. години био међу највећим у околним земљама, тако да је Србија била рангирана међу њима најлошије, на 101. месту. У 2014. Србија је побољшала позицију на ранг-листи за седам места (попела се на 94. место). Према подацима Извештаја СЕФ за 2015. годину, Србија је задржала позицију из претходне године (94. место од 140 земаља); при чему је од транзиционих земаља централне и југоисточне Европе само привреда Босне и Херцеговине лошије рангирана (налази се на 111. месту).
} 
анализираном периоду постоји повезаност између динамичног процеса либерализације спољне трговине земље, благог опоравка БДП-а и раста извоза и увоза.

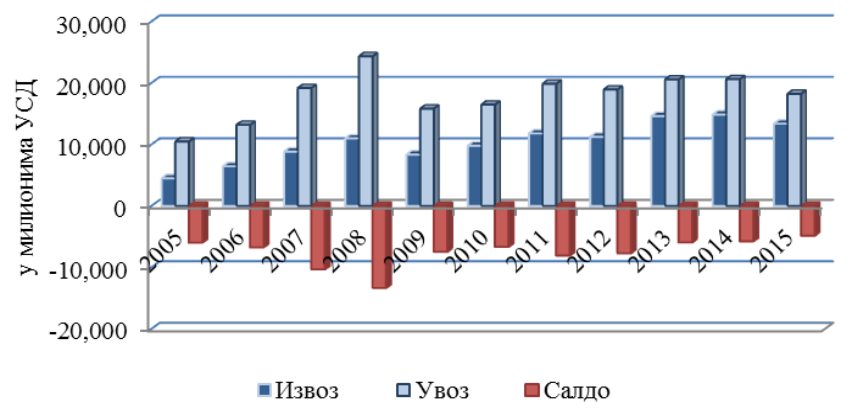

График 1. Спољнотрговинска размена Србије у периоду 2005-2014. године

Извор: Илустрација аутора на основу података РЗС

Коефичијент отворености српске економије повећао се са просечних 63\%, у трогодишњем периоду 2005-2007. година, на преко $80 \%$ последњих година. Склоност извозу значајно се повећала будући да је удео српског извоза у БДП са око једне петине повећан на преко једне трећине. Међутим, и поред споријег темпа раста учешћа увоза у БДП, постоји још увек значајна увозна зависност српске привреде, која износи нешто мање од $50 \%$. Овим се потврђују резултати ранијих истраживања да мале земље имају скромну ресурсну базу, због чега су високозависне од спољне трговине, али да је висок ниво отворености њихових економија пре резултат њихове веће увозне зависности, него склоности извозу (Бољановић, 2013; Тешић, 2013).

Значајан показатељ успешности, односно конкурентности привреде, јесте степен покривености увоза извозом, који се у Србији углавном повећавао - са мање од једне половине (46\%), колико је просечно износио у предкризном периоду, на око $72 \%$ последњих година.

Релативно велики спољнотрговински дефицит укупне размене Србије, који је у периоду 2005-2007. године просечно износио око 7,7 милијарди УСД (односно 23,7\% БДП), у наредним годинама је смањен, али његово учешће и даље премашује 13\% БДП и упућује на незадовољавајућу конкурентност укупне економије. Утврђени $и н$ декс откривене компаративне предности (RCA) потврђује претходну тврдњу. У свим годинама анализе, RCA има вредности мање од нуле, што указује на то да не постоје откривене компаративне предности српске привреде у размени са светом. У периоду од 2005. до 2015. године RCA показује извесно повећање компаративних предности укупне размене Србије са светом (Табела 1). 


\section{1. Степен концетраиије и диверзификаиије извоза и увоза укупне економије Србије}

Либерализација спољнотрговинске размене Србије условила је њен раст, при чему је извоз постао диверзификованији, што потврђују и коефицијенти концентрације и диверзификације извоза и увоза (Табела 2). Приказане вредности индекса концентрације показују да српски извоз има већи ниво концентрације у односу на увоз током читавог периода (осим у последњој години анализе), што је и разумљиво за малу економију, код које се очекује већи степен специјализације у извозу (Табела 2). Током анализираног периода запажа се опадање индекса концентрације извоза са либерализацијом спољнотрговинске размене и отварањем међународног тржишта за наше производе, што указује на сваштарење и већу диверзификацију извоза, односно његову изузетно ниску специјализацију.

Табела 2. Индекси конщентраиије и диверзификаиије спољнотрговинске размене Србије у периоду 2005-2014. година

\begin{tabular}{|c|c|c|c|c|c|c|c|c|c|c|}
\hline Показатељ & 2005. & 2006. & 2007. & 2008. & 2009. & 2010. & 2011. & 2012. & 2013. & 2014. \\
\hline $\begin{array}{l}\text { Индекс } \\
\text { концентра } \\
\text { ције извоза }\end{array}$ & 0,105 & 0,123 & $0,106^{*}$ & 0,088 & 0,066 & 0,077 & 0,074 & 0,068 & 0,114 & 0,105 \\
\hline $\begin{array}{l}\text { Индекс } \\
\text { концентра- } \\
\text { ције увоза }\end{array}$ & 0,084 & $0,076^{*}$ & 0,067 & 0,079 & 0,165 & 0,149 & 0,082 & 0,077 & 0,094 & 0,109 \\
\hline $\begin{array}{l}\text { Индекс } \\
\text { диверзи- } \\
\text { фикације } \\
\text { извоза } \\
\end{array}$ & 0,580 & 0,594 & $0,590^{*}$ & 0,549 & 0,525 & 0,542 & 0,538 & 0,515 & 0,534 & 0,521 \\
\hline $\begin{array}{l}\text { Индекс } \\
\text { диверзи- } \\
\text { фикације } \\
\text { увоза }\end{array}$ & 0,315 & $0,282 *$ & 0,277 & 0,282 & 0,335 & 0,355 & 0,320 & 0,313 & 0,327 & 0,339 \\
\hline
\end{tabular}

увоза

*Мање поуздане вредности

Извор: UNCTADStat http://unctadstat.unctad.org/wds/TableViewer/tableView.aspx

Мале земље услед скромних ресурса и мале величине домаћег тржишта не могу да развијају све привредне гране и остваре значајну диверзификацију производње и извоза, већ се одлучују за развијање привредних грана у којима могу да остваре компаративну предност - радно и ресурсно интензивне гране (Бољановић, 2013). Индекси концентрације извоза ових земаља су по правилу већи у односу на индексе земаља са напреднијом привредном структуром, што потврђују утврђени индекси за Албанију $(0,297)$; Црну Гору $(0,234)$ и Македонију $(0,189)$ (Табела 3$)$. Албанија је сврстана међу првих де- 
сет земаља у свету са највећим индексом концентрације (Beaulieu and Song, 2015).

Међу државама у окружењу, Србија (уз Босну и Херцеговину) има у 2014. години најнижи индекс концентрације извоза, који никако нија потврда конкурентности привреда ових држава и широког асортимана производа које могу понудити светском тржишту, већ недостатка осмишљене извозне стратегије препознатљивог националног извоза.

Табела 3. Индекси конщентраиије и диверзификаиије извоза држава Западног Балкана и просек за ЕУ-28 у 2014. години

\begin{tabular}{|c|c|c|c|c|c|c|c|c|}
\hline Показатељ & Србија & $\begin{array}{c}\text { Алба- } \\
\text { нија }\end{array}$ & БиХ & $\begin{array}{l}\text { Црна } \\
\text { Гора }\end{array}$ & $\begin{array}{l}\text { Маке- } \\
\text { донија }\end{array}$ & $\begin{array}{c}\text { Мол- } \\
\text { давија }\end{array}$ & $\begin{array}{c}\text { Хрват- } \\
\text { ска }\end{array}$ & EУ-28 \\
\hline $\begin{array}{l}\text { Индекс } \\
\text { концентрације } \\
\text { извоза } \\
\end{array}$ & 0,105 & 0,297 & 0,104 & 0,234 & 0,189 & 0,146 & 0,078 & 0,064 \\
\hline $\begin{array}{l}\text { Индекс } \\
\text { диверзифика- } \\
\text { ције извоза }\end{array}$ & 0,521 & 0,701 & 0,614 & 0,711 & 0,698 & 0,669 & 0,474 & 0,224 \\
\hline
\end{tabular}

Извор: UNCTADStat

Развијеније земље одликују нешто нижи индекси концентрације, који се могу објаснити чињеницом да те земље производе широк асортиман готових производа, што им омогућава бољу позицију на светском тржишту. Просечан индекс концентрације за ЕУ-28 износи 0,064 и знатно је нижи у односу на државе чланице CEFTA. Структуру извоза развијених земаља карактерише веће учешће производа више фазе финализације, а већа диверзификација извоза смањује преношење поремећаја са светског на тржиште ових земаља.

Индекси диверзификације извоза имају мање вредности за развијене земље (ЕУ-28), док Србија, као и већина земаља у окружењу (осим Хрватске), има висок ниво индекса диверзификације извоза, што потврђује да се структура извоза ових земаља знатно разликује од структуре светског просека. Индекси диверзификације српског увоза нижи су у односу на вредности индекса диверзификације извоза, што указује на то да се структура увоза Србије мање разликује од структуре светског просека.

\section{2. Структура извоза и увоза укупне економије Србије}

У структури српског извоза доминирају сектори: 0 - Храна и живе животиње, 6 - Израђени производи сврстани по материјалу и 7 - Машине и транспортни уређаји (Табела 4). Током посматраног периода запажају се извесне промене у структури српског извоза. Док се учешће сектора 0 није значајније променило и износи око $16 \%$, 
учешће сектора 6 , који чине разни полупрерађени производи, смањује свој удео са 36 на $21 \%$ (тако да се удео ова два сектора смањио са око $52 \%$ на $37 \%$ ).

Табела 4. Структура укупног извоза Србије по секторима СМТК у периоду 2005-2014. година (\%)

\begin{tabular}{lrrrr}
\hline \multirow{2}{*}{ Сектори СМТК } & $\varnothing(2005$ & $\emptyset(2008$ & $\varnothing(2011$ & 2014. \\
& $-2007)$ & $-2010)$ & $-2013)$ & \\
\hline 0- Храна и живе животиње & 16,4 & 16,6 & 16,9 & 15,9 \\
1 - Пића и дуван & 1,7 & 2,5 & 2,4 & 2,7 \\
2 - Сирове материје, нејестиве, осим горива & 4,5 & 4,1 & 5,0 & 3,7 \\
3 - Минерална горива, мазива и сродни производи & 3,3 & 4,4 & 4,2 & 3,7 \\
4 - Животињска и биљна уља, масти и воскови & 0,8 & 1,4 & 1,6 & 1,0 \\
5 - Хемијски и сл. производи, нигде непоменути & 10,5 & 9,0 & 8,4 & 8,0 \\
6 - Израђени производи сврстани по материјалу & 36,1 & 29,3 & 24,1 & 20,9 \\
7 - Машине и транспортни уређаји & 11,7 & 17,0 & 23,5 & 30,1 \\
8 - Разни готови производи & 14,4 & 14,3 & 13,1 & 13,1 \\
9- Производи непоменути у СМТК рев. 4 & 0,7 & 1,3 & 0,9 & 0,8 \\
\hline
\end{tabular}

Извор: Обрачун аутора на основу података РЗС

На извесно поправљање структуре српског извоза указује повећан удео сектора 7 - Машине и транспортни уређаји са око 12 на $30 \%$, будући да ови и хемијски производи (сектор 5) представљају производе највише фазе прераде. И поред значајног повећања удела сектора 7, удео прерађивачке индустрије (сектори 5-8) у вредности српског извоза није се значајно променио (око 70\%), будући да је смањено учешће остала три сектора, посебно сектора 6 - Израђени производи сврстани по материјалу и 5 - Хемијски и слични производи.

За потпуније сагледавање обележја спољнотрговинске размене Србије неопходно је размотрити и структуру увоза. Током читавог периода анализе, највећу заступљеност у вредности српског увоза има сектор 7, која се уз извесне осцилације углавном повећавала и последњих година премашује 26\% (Табела 5). Поред овог, значајно су заступљени сектори: 3 - Минерална горива, са опадајућим уделом; 5 - Хемијски и слични производи, са благим порастом и 6 Израђени производи, сврстани по материјалу, са смањеним учешћем. 
Табела 5. Структура укупног увоза Србије по секторима СМТК у периоду 2005-2014. година (\%)

\begin{tabular}{|c|c|c|c|c|}
\hline Сектори СМТК & $\begin{array}{c}\emptyset(2005 \\
-2007)\end{array}$ & $\begin{array}{l}\varnothing(2008 \\
-2010)\end{array}$ & $\begin{array}{l}\varnothing(2011 \\
-2013)\end{array}$ & 2014. \\
\hline 0 - Храна и живе животиње & 4,7 & 4,5 & 5,7 & 6,4 \\
\hline 1 - Пића и дуван & 0,9 & 0,7 & 1,0 & 1,0 \\
\hline 2 - Сирове материје, нејестиве, осим горива & 4,1 & 3,5 & 3,5 & 3,2 \\
\hline 3 - Минерална горива, мазива и сродни производи & 18,4 & 17,7 & 17,5 & 14,1 \\
\hline 4 - Животињска и биљна уља, масти и воскови & 0,2 & 0,2 & 0,3 & 0,3 \\
\hline 5 - Хемијски и сл. производи, нигде непоменути & 13,1 & 12,8 & 15,6 & 14,9 \\
\hline 6 - Израђени производи сврстани по мат. & 20,0 & 17,5 & 18,3 & 17,9 \\
\hline 7 - Машине и транспортни уређаји & 24,0 & 19,9 & 24,8 & 26,4 \\
\hline 8 - Разни готови производи & 8,2 & 7,7 & 7,5 & 7,8 \\
\hline 9 - Производи непоменути у СМТК рев. 4 & 6,4 & 15,3 & 5,8 & 8,0 \\
\hline
\end{tabular}

Учешће сектора 0 - Храна и живе животиње у вредности српског увоза у посматраном периоду благо се повећало, са 4,7 на $6 \%$, док сектор 1 - Пића и дуван остварује удео од око једног процента, а за сектор 4 - Животињска и биљна уља и масти то учешће износи скромних $0,3 \%$.

\section{3. Степен покривености увоза извозом укупне економије Србије}

Значајан показатељ конкурентности привреде је степен покривености увоза извозом. Са отварањем привреде и либерализацијом спољнотрговинске размене након 2000. године, степен покривености увоза извозом у Србији континуирано се смањивао, док је раст конкурентности присутан у годинама након светске економске кризе. Најнижи степен покривености увоза извозом, током последње деценије, постојао је у периоду 2005-2007. године, када је 46\% плаћања по основу робног увоза Србије било покривено извозним приходима (Табела 6). У 2014. години покривеност увоза извозом повећана је на $72 \%$.

Анализа степена покривености по секторима указује на то да је секторска конкурентност донекле измењена у последњој деценији. У првом посматраном трогодишту (2005-2007) три сектора имала су степен покривености изнад 100\% (0 - Храна и живе животиње, 1 Пића и дуван и 4 - Животињска и биљна уља и масти), док се њихов број у 2014. години повећао на четири (укључивањем сектора 8 Разни готови производи). Три сектора имају степен покривености у интервалу од 50 до 100\%, а код осталих је испод 50\% (Табела 7).

Само три сектора (0 - Храна и живе животиње, 1 - Пиће и дуван и 4 - Животињска и биљна уља и масти) током читавог посматраног периода имају степен покривености увоза извозом већи од $100 \%$. Овим се потврђује да највиши степен конкурентности одли- 
кује примарне производе, првенствено оне који припадају аграрном сектору.

У свим секторима прерађивачке индустрије постоји низак степен покривености увоза извозом у посматраном периоду, а у три сектора је, и поред извесног пораста, у свим годинама мањи од $100 \%$ (5, 6 и 7). Изузетак је сектор 8 - Разни готови производи, који последњих година остварује степен покривености већи од 100\%. Сектор 7 Машине и транспортни уређаји представља најсофистициранији сектор и остварује висок раст степена покривености (за скоро 60 процентних поена), али је он и даље мањи од 100\%, што упућује на његову неконкурентност. Ово је последица застареле технологије и опреме и недовољних иновација које укључују нова техничкотехнолошка решења која би учинила овај сектор конкурентнијим.

Изузетно низак ниво конкурентности и степен покривености испод $20 \%$ током посматраног периода имају сектор 3 и сектор 9.

Табела 6. Степен покривености увоза извозом Србије по секторима СМТК за период 2005-2014. година (\%)

\begin{tabular}{|c|c|c|c|c|}
\hline Сектори СМТК & $\begin{array}{c}\varnothing(2005 \\
-2007) \\
\end{array}$ & $\begin{array}{c}\varnothing(2008 \\
-2010) \\
\end{array}$ & $\begin{array}{c}\varnothing(2011 \\
-2013) \\
\end{array}$ & 2014. \\
\hline 0 - Храна и живе животиње & 168,6 & 192,2 & 187,5 & 179,5 \\
\hline 1 - Пића и дуван & 104,5 & 194,8 & 148,1 & 186,6 \\
\hline 2 - Сирове материје, нејестиве, осим горива & 51,5 & 61,8 & 91,9 & 82,3 \\
\hline 3 - Минерална горива, мазива и сродни производи & 8,1 & 13,4 & 15,7 & 19,0 \\
\hline 4 - Животињска и биљна уља, масти и воскови & 214,9 & 314,4 & 368,4 & 250,1 \\
\hline 5 - Хемијски и сл. производи, нигде непоменути & 37,3 & 37,1 & 34,1 & 39,0 \\
\hline 6-Израђени производи сврстани по материјалу & 83,5 & 87,7 & 82,1 & 84,2 \\
\hline 7 - Машине и транспортни уређаји & 23,1 & 44,9 & 59,6 & 82,2 \\
\hline 8 - Разни готови производи & 81,5 & 96,7 & 110,5 & 121,1 \\
\hline 9 - Производи непоменути у СМТК рев. 4 & 115,8 & 7,0 & 9,9 & 7,3 \\
\hline Укупно & 45,9 & 52,5 & 63,2 & 72,0 \\
\hline
\end{tabular}

Извор: Обрачун аутора на основу података РЗС

\section{4. Откривене компаративне предности укупне економије Србије}

Анализа откривене компаративне предности по појединим секторима укупне економије Србије указује на њихову различиту конкурентску позицију у размени са светом. Компаративне предности остварене су претежно код примарних производа, што је у складу са нивоом економског развоја, расположивошћу природних ресурса и ценом фактора производње радне снаге (Jefersson Institute, 2003).

Позитивне вредности RCA показатеља имају сектори 0 - Храна и живе животиње, 1 - Пића и дуван, 4 - Животињска и биљна уља и масти и 8 - Разни готови производи, што указује на то да Србија има компаративне предности у размени ових сектора са светом (Та- 
бела 7). Највиши ниво конкурентности има сектор $4(0,43)$, а потом сектор $1(0,30)$ и сектор $0(0,28)$.

Сви сектори прерађивачке индустрије, осим 8 - Разни готови производи, имају негативне вредности RCA индекса. Овим се потврђује констатација о њиховој неконкурентности изведена на основу претходно утврђеног показатеља - степена покривености увоза извозом. Раст конкурентности ових сектора захтева значајна улагања у нову опрему и технологију и превазилажење заосталости у односу на привредно развијеније земље.

Табела 7. Откривене компаративне предности спољне трговине Србије (RCA) по секторииа СМТК у 2014. години

\begin{tabular}{lr}
\hline Сектори СМТК & RCA \\
\hline 0 - Храна и живе животиње & 0,28 \\
1 - Пића и дуван & 0,30 \\
2 - Сирове материје, нејестиве, осим горива & $-0,10$ \\
3 - Минерална горива, мазива и сродни производи & $-0,68$ \\
4 - Животињска и биљна уља, масти и воскови & 0,43 \\
5 - Хемијски и сл. производи, нигде непоменути & $-0,44$ \\
6 - Израђени производи сврстани по материјалу & $-0,09$ \\
7 - Машине и транспортни уређаји & $-0,10$ \\
8 - Разни готови производи & 0,10 \\
9 -Производи непоменути у СМТК рев. 4 & $-0,86$ \\
\hline Укупно & $-0,16$ \\
\hline
\end{tabular}

Извор: Обрачун аутора на основу података РЗС

\section{5. ЗНАЧАЈ АГРАРНОГ СЕКТОРА У СПОЉНОТРГОВИНСКОЈ РАЗМЕНИ СРБИЈЕ}

Повећана отвореност привреде и либерализација спољнотрговинске размене у последњој деценији условили су динамичан раст вредности размене аграрног сектора Србије. Извоз пољопривреднопрехрамбених производа брже је растао у односу на увоз, што је резултирало повећањем позитивног спољнотрговинског салда. Вредност аграрног извоза Србије у 2014. години премашила је три милијарде УСД, односно повећала се за $138 \%$ у односу на просек за први трогодишњи период у посматраној деценији (Табела 9). Учешће извоза пољопривредно-прехрамбених производа у укупном БДП Србије повећано је са 4 на око $7 \%$. 
Табела 8. Спољнотрговинска размена пољопривредно-прехрамбених производа (nпn) и њихово учешће у укупној размени Србије у периоду 2005-2014. године

\begin{tabular}{|c|c|c|c|c|c|}
\hline Показатељ & $\begin{array}{l}\varnothing(2005 \\
-2007)\end{array}$ & $\begin{array}{l}\varnothing(2008 \\
-2010)\end{array}$ & $\begin{array}{l}\varnothing(2011 \\
-2013)\end{array}$ & 2014. & $\begin{array}{c}\text { Индекс } \\
2014 / \varnothing \\
(2005-2007)\end{array}$ \\
\hline БДП (мил. УСД) & $32.394,3$ & $43.759,6$ & $44.217,2$ & $44.143,1$ & 136 \\
\hline Извоз - ппп (мил. УСД) & $1.288,9$ & $2.046,3$ & $2.733,4$ & $3.068,0$ & 238 \\
\hline Учешће извоза ппп у БДП (\%) & 4,0 & 4,7 & 6,2 & 6,9 & \\
\hline Увоз - ппп (мил. УСД) & 833,7 & $1.103,3$ & $1.506,8$ & $1.729,2$ & 207 \\
\hline Салдо - ппп (мил. УСД) & 455,2 & 943,0 & $1.226,6$ & $1.338,8$ & 294 \\
\hline $\begin{array}{l}\text { Степен покривености увоза } \\
\text { извозом ппп }\end{array}$ & 154,2 & 185,8 & 181,9 & 177,4 & - \\
\hline $\begin{array}{l}\text { Учешће извоза ппп у укупном } \\
\text { извозу (\%) }\end{array}$ & 19,6 & 21,1 & 21,8 & 20,7 & - \\
\hline $\begin{array}{l}\text { Учешће увоза ппп у укупном } \\
\text { увозу (\%) }\end{array}$ & 5,8 & 5,8 & 7,6 & 8,4 & - \\
\hline RCA & 0,20 & 0,30 & 0,29 & 0,28 & - \\
\hline
\end{tabular}

Извор: Обрачун аутора на основу података РЗС

У истом периоду увоз пољопривредно-прехрамбених производа повећан је на 1,7 милијарди УСД, односно за 107\%, а спољнотрговински салдо остварио је раст од $194 \%$ и достигао вредност од 1,3 милијарде УСД.

Степен покривености увоза извозом пољопривредно-прехрамбених производа током последње деценије остварује вредности веће од 100\%, што упућује на значајну конкурентност аграрног сектора Србије, која га издваја од свих преосталих сектора српске економије. У условима значајнијег отварања земље и либерализације спољнотрговинске размене Србије, присутне су одређене осцилације степена покривености. Најнижи је био у првом посматраном трогодишњем периоду (2005-2007. година), када је износио 154\%, док је у наредном трогодишту (2008-2010. година) достигао највећи ниво и просечно износио $186 \%$. У условима све значајнијег отварања привреде и либерализације трговине, првенствено са чланицама ЕУ, наредних година присутно је благо смањење степена покривености увоза аграрних производа на, још увек високих, 177\% у 2014. години.

Наведене тенденције у размени пољопривредно-прехрамбених производа и у укупној спољнотрговинској размени Србије условиле су високо учешће аграрног сектора, које се током последње деценије углавном повећава и премашује $20 \%$ укупног извоза. Удео пољопривредно-прехрамбених производа у укупном српском увозу се током последње деценије повећавао и последњих година усталио на око 8\%.

Висок удео аграрног сектора у спољнотрговинској размени Србије може се објаснити повољним природним условима и богатим 
ресурсима за развој пољопривреде, као и спорим развојем других привредних грана, пре свега индустрије, и смањеним уделом производа ове делатности у размени.

Анализа откривене компаративне предности, изведена за поједине робне групе унутар аграрног сектора у 2014. години, потврђује да у размени са светом Србија има компаративне предности код примарних производа и прозвода нижег степена прераде. Издвојено је 20 робних група пољопривредно-прехрамбених производа са највећим вредностима RCA. Групе производа код којих Србија има највеће компаративне предности су: сирово крзно, житарице (пшеница, кукуруз) и производи нижих фаза прераде (прекрупа, брашно) - Табела 9. Висока позитивна вредност RCA индикатора за робну групу сирово крзно резултат је изостанка увоза у посматраној години.

Табела 9. Двадесет робних група СМТК пољопривредно-прехрамбених производа са највећим RCA рангираних по вредности у 2014. години

\begin{tabular}{cclr}
\hline $\begin{array}{c}\text { Редни } \\
\text { број }\end{array}$ & $\begin{array}{c}\text { Ознака } \\
\text { произвда }\end{array}$ & Назив производа & RCA \\
\hline 1. & 212 & Сирово крзно & 1,00 \\
\hline 2. & 041 & Пшеница и наполица, у зрну & 0,98 \\
3. & 047 & Прекрупа и брашно од осталих житарица & 0,91 \\
\hline 4. & 046 & Брашно, прекрупа и гриз, од пшенице & 0,89 \\
\hline 5. & 044 & Кукуруз, у зрну & 0,88 \\
6. & 421 & Чврсте биљне масти, уља 'мека' & 0,84 \\
7. & 058 & Воће припремљено и производи(осим сокова) & 0,82 \\
8. & 061 & Шећер, меласе и мед & 0,66 \\
\hline 9. & 043 & Јечам, у зрну & 0,64 \\
10. & 111 & Безалкохолна пића, непоменута на другом месту & 0,63 \\
\hline 1. & 024 & Сир и урда & 0,52 \\
12. & 223 & Уљано семење за остала уља & 0,50 \\
13. & 011 & Месо говеђе, свеже, расхлађено или смрзнуто & 0,48 \\
14. & 059 & Сокови од воћа и поврћа, неферм., без алкохола & 0,45 \\
15. & 023 & Маслац и остале масноће од млека; млечни намази & 0,39 \\
16. & 291 & Животињске сирове материје, нн & 0,38 \\
17. & 048 & Производи од житарица, брашна, скроба & 0,33 \\
\hline 18. & 122 & Дуван, прерађен & 0,31 \\
\hline 19. & 075 & Зачини & 0,27 \\
20. & 112 & Алкохолна пића & 0,23 \\
\hline
\end{tabular}

Сокови од воћа и поврћа, производи од житарица и брашна, као производи више фазе прераде, одликују се нижим вредностима RCA, што указује на то да у размени са овим производима Србија остварује знатно мању конкурентност у размени на светском тржишту. 


\section{ЗАКЉУЧАК}

Економски систем Србије постаје све отворенији, са још увек релативно високом увозном зависношћу, скромним и неконкурентним извозом и ниским степеном покривености увоза извозом. Коефицијент отворености српске економије се у посматраном периоду 2005-2014. година повећао са око 60 на преко 80\%. Међутим, и поред споријег темпа раста учешћа увоза у БДП, постоји још увек значајна увозна зависност српске привреде, која износи скоро 50\%, чиме се потврђује тврдња да је висок ниво отворености малих економија више резултат њихове веће увозне зависности него склоности извозу.

Спољнотрговинску размену укупне економије Србије карактерише велики дефицит, неповољна структура и остварена компаративна предност код примарних производа и оних ниже фазе прераде. Релативно велики спољнотрговински дефицит укупне размене Србије је смањен, али његово учешће и даље премашује $13 \%$ БДП и упућује на незадовољавајућу конкурентност укупне економије. Утврђени индекс откривене компаративне предности (RCA), који на нивоу укупне трговине представља однос спољнотрговинског салда и укупног обима размене са светом, потврђује претходну тврдњу.

Међу државама чланицама CEFTA, Србија (уз Босну и Херцеговину) има најнижи индекс концентрације извоза, који никако нија потврда конкурентности привреде и широког асортимана производа који могу да се понуде светском тржишту, већ недостатка осмишљене извозне стратегије, што је условило велику диверзификацију извоза.

У структури српског извоза доминирају сектори: 0 - Храна и живе животиње, 6 - Израђени производи сврстани по материјалу и 7 - Машине и транспортни уређаји. Анализа степена покривености по секторима указује на то да највиши степен конкурентности одликује примарне производе, првенствено оне који припадају аграрном сектору. RCA показатељи откривене компаративне предности у трговини по појединим секторима потврђују постојање компаративних предности Србије у размени са светом наведеним примарним производима.

Анализа обележја спољнотрговинске размене српске економије указује на значајну улогу аграрног сектора у њеној структури, смањивању спољнотрговинског дефицита и повећању укупне конкурентности. Значај аграрног сектора у спољнотрговинској размени огледа се у смањивању спољнотрговинског дефицита, будући да почев од 2005. године континуирано остварује позитиван спољнотрговински биланс, а учешће овог сектора у укупном извозу остварује раст и последњих година премашује $20 \%$. Анализа откривене компаративне предности, изведена за поједине робне групе пољопривредно-прехрамбених производа у 2014. години, потврђује да у размени са све- 
том Србија има компаративне предности код примарних пољопривредних производа и прозвода нижег степена прераде.

\section{ЛИТЕРАТУРА}

Balassa, B. (1965). Trade Liberalisation and "Revealed Comparative Advantage", The Manchester School of Economic and Social Studies, 33, 99-123.

Beaulieu, E. \& Song, Y. (2015). What Dependency Issues? University of Calgary, Vol 8, Issue 3.

Bojnec, Š. \& Fertö, I. (2007). Comparative Advantages in Agro-Food Trade of Hungary, Croatia and Slovenia with the European Union. Discussion Paper No. 106, IAMO, Halle, Germany.

Бољановић, С. (2013). Компаративна анализа утицаја страних директних инвестиција на структуру и специјализацију српског и мађарског извоза (А Comparative Analysis of the Impact of Foreign Direct Investments on the Structure and Specialization of Serbian and Hungarian exports), Економске теме, $51(1), 37-57$

Božić, D., Nikolić, M. (2013-a). Significance and Comparative Advantages of the Agrarian Sector in Serbian Foreign Trade. In Agriculture and Rural DevelopmentChallenges of Transition and Integration Processes, $50^{\text {th }}$ Anniversary of Department of Agricultural Economics, Faculty of Agriculture, University of Belgrade, pp. 13-31.

Božić, D., Nikolić, M. (2013-b). Regional Analysis of Agricultural and Food Trade of Serbia, 135 EAAE Seminar Challenges for the Global Agricultural Trade Regime after Doha, pp. 83-98.

Fertö, I. \& Hubbard, J. L. (2002). Revealed Comparative Advantage and Competitiveness in Hungarian Agri-Food Sectors. Institute of Economics Hungarian Academy of Sciences Discussion Papers, 2002/8, Budapest.

Јаћимовић, Д., Бјелић, П., Марковић, И. (2013). Утицај светске економске кризе на међународне инвестиционе и трговинске токове у регион Западног Балкана (The Impact of the World Economic Crisis on Foreign Investments and Trade Flows in the Western Balkans), Економске теме, 51 (1), 1-20.

Jefferson Institute (2003). Конкурентност привреде Србије (Competitiveness of the Serbian Economy).

Liesner, H. H. (1958). The European Common market and British industry. Economic Journal, 68, 270, 302-316.

Olteanu, D. (2009). Technological specialisation of production and export in Europe, National Institute of Economic Research Working Paper 090108.

Републички завод за статистику Србије: База података, РЗС, Београд (Statistical Office of the Republic of Serbia: Databases, SORS, Belgrade).

Тешић, J. (2013). Отвореност и конкурентност малих транзиционих привреда (Openness to Trade and Competitiveness of Small Transitional Economies), Acta Economica, година XI, бр 18, 317-336.

UNComtrade, http://comtrade.un.org

United Nations Conference for Trade and Development, UNCTAD's Trade Analysis and Information System - TRAINS Database http://unctadstat.unctad.org

World Bank, http://www.worldbank.org

World Bank, World Integrated Trade Solution Database, http://wits.worldbank.org/wits/

World Economic Forum (2015). Global Competitiveness Report 2015-2016, Geneva. 


\title{
SERBIAN FOREIGN TRADE AND IMPORTANCE OF AGRARIAN SECTOR
}

\author{
Dragica Božić, Marija Nikolić \\ University of Belgrade, Faculty of Agriculture, Belgrade, Serbia
}

\begin{abstract}
Summary
The position of a country on the world market is determined by the degree of its integration into international trade processes. Smaller economies are concentrated on labor and resource intensive industries and achieve concentration on a few key products in exports, while countries at a higher level of economic development increase the dependence on exports. Perceiving the characteristics and performance of foreign trade is important in terms of the stability of economic trends at the national level.

The first part of the paper is dedicated to the analysis of the Serbian total trade with the world, while in the second part the relevance and competitiveness of agrarian products are examined. The research results indicate that the foreign trade of Serbia is characterized by a constant deficit in the period 2005-2014, although a slight recovery is recorded after the global economic crisis. These results were confirmed by using different indicators. The coverage of imports by exports of overall economy increased from minimum $46 \%$ at the beginning of the period to about $72 \%$, indicating a reduction in the trade deficit. The openness index of economy also points to the acceleration of foreign trade and deficit reduction, which is a result of increased export propensity from 20.0 to $33.6 \%$.

Constant deficit of the total economy was accompanied by a low level of competitiveness of the Serbian economy. The index of Revealed Comparative Advantage (RCA) also indicates at the unsatisfactory competitiveness of the overall economy, which throughout the period has a value less than zero, although in recent years indicates a certain increase.

In addition to the analysis of the dynamics of foreign trade flows, significnt attention was given to the consideration of their structure. The calculated concentration indexes show that Serbian exports have a higher level of concentration than imports, which is characteristic for less developed economies. The Serbian index of export diversification has a relatively high value, which means that the structure of export is significantly different than the world average. In the structure of export sectors 0-Food and live animals, 6-Manufactured goods classified by material and 7-Machinery and transport equipment dominate. Index of diversification of import has a slightly lower value and indicates that the import of Serbia has more similar structure to the world average. The biggest shares in import have sectors 7, 6 and 3-Mineral fuels.

The only sectors that achieved a surplus, the level of coverage of imports by exports greater than $100 \%$, or the positive value of RCA index in the observed period are 0-Food and live animals, 1-Beverages and tobacco and 4-Animal and vegetable oils and fats. This confirms that the highest level of competitiveness is characteristic for the primary products, or those from agrarian sector. Surplus of agrarian products in recent years has detected growth as a result of increased openness of the economy and liberalization of foreign trade. The agrarian sector accounts for a high proportion of total trade, which over the last decade exceeded $20 \%$ of total exports, while in the imports was stabilized at around $8 \%$.

Within the agrarian sector of Serbia, comparative advantages were revealed in trade of primary products and products of lower level of processing, such as grains, whole wheat and flour, while juices from fruit and vegetables, dairy products and cereal products, as well as products of higher level of processing, are less competitive.
\end{abstract}

